\title{
Learning Worship as a Way to Improve Students' Discipline, Motivation, and Achievement at School
}

\author{
Rifa Hidayah ${ }^{1}$ \\ Maulana Malik Ibrahim State Islamic University (UIN) Malang \\ Elfi Mu'awanah \\ Sayyid Ali Rahmatullah State Islamic University (UIN) Tulungagung
}

Arif Zamhari

Syarif Hidayatullah State Islamic University (UIN) Jakarta

Munardji

Sayyid Ali Rahmatullah State Islamic University (UIN) Tulungagung

Naqiyah

Prof. Saifuddin Zuhri State Islamic University (UIN) Purwokerto

\begin{abstract}
A discipline of worship and seems to be associated with the fact that students who apply discipline in worship should demonstrate more autonomy in school. This research used a case study design with a qualitative approach to data analysis. Participants in this study included four sixth-grade students, two teachers, and one principal from Tulungagung, East Java, Indonesia. The data for this study were gathered through direct observation and an in-depth interview. Direct observation was used to immerse students in how they perform their worship and Islamic beliefs at home and at school in order for them to be aware of their faith, worship, and application in their daily lives, and thus disciplines at schools, motivation to learn, and efforts to increase academic attainments are identified. Throughout the study, in-depth interviews with teachers, principals, and parents were conducted three times, and all were registered verbatim. To describe both numeric data and themes, data was analyzed using content analysis. The findings indicate that worships contribute significantly to internal and practical discipline efforts and behaviors. Students' future and proper insight into education opportunities and their future of existence are threatened by their knowledge of worship. Psychologically, students do well in terms of motivation and academic achievement. After receiving teaching worship, selfconfidence, trust, spirit, belief, and self-efficacy all improve.
\end{abstract}

Keywords: attitude, discipline, school value, self-reliance, worship.

We see how people shape personalities, particularly children, who often learn behaviors from their parents, such as religious practices, and how they form personalities (Xia et al., 2013). Adu-Gyamfi (2020) emphasized the importance of family resilience, citing Al Quran of Al Thalaq: 2-3, because it leads to a religious sense that prepares children for the future. Being self-sufficient with a strong foundation in religious values is a valuable asset in one's life

\footnotetext{
${ }^{1}$ Corresponding Author E-Mail: rifa_hidayah@psi.uin-malang.ac.id
} 
(Gunay \& Aydin, 2015). Positive behavior is shown when a person who is often under great stress manages to control it well (Drake et al., 2011; Kalimullina et al., 2021). Religious discipline encourages individuals to behave positively in families (Weiss et al., 2013), so all family members' behavioral patterns will be better, thereby helping to maintain the integrity of the entire family unit as well as the individual family members (Ahmadi, 2021; Polat, 2020). In this manner, challenges appear in that minority students faced in this context, and the students' academic performance of the minority students was poor. Race, social class, background, masculinity, culture, religion, and faith are all identified as challenges in this novel (Ahmed \& Memish, 2019; Capers, 2019). Religion and faith, on the other hand, were identified as having a significant impact on minority students' academic success (Glaeser \& Sacerdote, 1999; Logan, 2013).

The resilience built among the family and its members positively influences how they support each other. This is important, because persistent family dysfunctions can have a detrimental effect on discipline and academic achievement at school (Ning, 2019). Nevertheless, God provides a treatment for all maladies (Tocco, 2017), and an adherence to religious practices may help students to achieve balance in their social interactions, beliefs, and responsibilities. Someone who develops a physical or psychological illness can benefit from a religious conviction in terms of being more successful in life again (Roth, 2020). Teaching religious is necessitated of establishing religious teachings, obligations, and observance, especially for people who encounter problems in life (Hidayah, 2021). When worship is appropriately followed, the values permeate into everyday life, and this includes discipline at school (Addai-Mununkum, 2019; Jeynes, 2003b; Sabirov et. al., 2021).

The difficulties that minority students face in some Indonesian schools include low academic achievement and motivation. The challenges include race, social class, gender, and faith, religion, which are all difficult to describe (Barlow \& Hersen, 1984). According to the data, religion and faith helped contribute significantly to the academic success of the lower socioeconomic class students (Jeynes, 2003a, 2003b; Suskind, 1998). Recent research into this area indicate that religious involvement and academic achievement are related. Vibrant spiritual and religious activities influence the learning outcomes of an individual (Jeynes, 2003a; Clark, 2004).

Hansen \& Ginsburg (1988) analyzed the Grade 10 students and find that the effect of religion as one factor of pro-social values on academic performance was greater than the effect of socioeconomic status. Students who are strongly committed to tradition have better scores on outcome assessments (Clauson, 2019). Students who have strong religious values outperform less religious students in terms of discipline (Capers, 2019). This research also discovered that having religious beliefs was linked to higher math scores (Hansen \& Ginsburg, 1988). According to social science studies, religious practice has a positive impact on children's educational achievement, which is particularly true for children from low-income communities (Jeynes, 2003a; Regnerus \& Elder, 2003). In many studies, however, researchers have found that students who do religious practices regularly at school tend to earn better grades, do more homework, while in school, and have fewer academic problems (Jeynes, 2003b; Logan, 2013).

We also believe that family life is important and that parents should play a role in the education of their children. Also, students should have fun while learning (Aronson et. al., 2020). They suggest that children must develop assets that are there all along the way in order to have success in the future, and discipline must be applied early to develop a passion for academic success (Ahmadi, 2021; Akpur, 2020). To guide this research, the following research questions were sought:

1. What aspects are served from the religious worship to improve school discipline?

2. How does learning worship improve motivation and academic achievement? 


\section{Literature Review}

\section{Discipline, Motivation, and Achievement at School}

The conditions within school affect students' mental processes and consequently their learning. A collaborative learning system, which focuses on the experiences of students, helps students to successfully complete their assignments, so such an educational milieu is highly desirable in schools (Bellfield et al., 2018; Bandura, 1977). While the learning environment is very important to academic achievement, the discipline of students is even more important (Skiba et al., 2016). Poor discipline at school is often observed in students in rural areas, who are often relatively deprived (William, Mcintosh \& Russel, 2021). Due to a low level of discipline, students may fail academically and even be expelled from school due to disruptive behavior that violates a school's policies (Bellinger et al., 2016), and it often hinders the learning process at school (Budiharso \& Tarman, 2020).

Understanding a student's level of discipline requires detailed background information (Bellinger et al., 2016). This includes the geographic and economic factors of the area and the family conditions for the student, such as whether it owns or rents a home, whether parents or grandparents live with the student, whether another family lives with them, the economic situation of the family, and the family's income (Pietkiewicz, Lecoq-Bamboche \& Hart (2019). Solutions for addressing disciplinary deficits (Bellinger et al., 2016; Solikhah \& Budiharso, 2020; Tamang \& Shrestha, 2021) include accommodating and listening to complaints, creating a safer school environment, challenging students to practice self-discipline and find solutions for themselves, and collaborating to transform negative aspects of the student by turning negative thinking into positive thinking (Warman, 2021). The greater the level of discipline, the better a student will learn (Huang \& $\mathrm{Zu}, 2017$ ). The most obvious sign of improved achievement is getting better grades over time. Even though a student's parents may be in a low economic category, a good school climate can improve that student's motivation (Li \& Qi, 2019; Yuden et al., 2020) and subsequent academic achievement (Patrikiosa \& Xezonakisb, 2019; Chen et al., 2020).

\section{Adherence to Worship Leads to Discipline at School}

Someone will get into trouble if they abandon worship. If someone follows worship practices, it will address problems at school and work (Ahmadi, 2021; QS Maryam: 29). The argument goes that someone who can practice discipline in religious worship can apply discipline in other situations (Adu-Gyamfi, 2020). Indeed, when someone adheres to compulsory worship (QS Al-Ankabut: 45), it helps that person to limit any negative behavior. Religious worship is a key element of religious life and an individual's struggle (Karimia \& Basu, 2018). Furthermore, when worship is performed in congregations and comes with other obligations, it encourages cooperation in stabilizing emotions, thus contributing to personal wellbeing (Deb, 2018; Salinas-Vasquez et. al., 2020).

A follower of a religion should prioritize worship in life (QS An Nuur: 56), because it only brings good things. Introducing children to worship early in life greatly improves its power for them. What is more, if parents do not worship, their children will tend to also not worship. Encouraging worship requires time and the nurturing of an individual awareness of prayer as a tool (Hutler, 2019). Worship improves a person's self-control, and elements of istiqomah (steadfastness) grow stronger (Ranz \& Alhuzai, 2019). Worship therefore becomes a habit of thoroughness (Abramowitz \& Hellberg, 2020), and someone with a strong religious faith is often characterized by regular worship and piety. 
Being disciplined in worship provides a basis for discipline at school and at work (Thomas et al., 2018). The Quran mandates worship as a guide for living life, so disciplined prayer is key to a person's success. If you build good religious values through worship, it is useful in wider life, including at school, because it supports self-discipline (Abramowitz \& Hellberg, 2020). Abramowitz and Hellberg (2020) found that those who adhere to Christianity and strong moral values in life tend to do extraordinary well in school and actively engage in various school and extra-curricular activities, as well as experience more self-control and satisfaction in their social lives. Religion therefore strongly influences school performance through discipline (Ragin, 2014). Children with weak religious convictions could therefore be offered opportunities to strengthen their faith as a way of improving their achievement at school (Vaughan, et. al., (2018).

\section{Teaching Worship as a Way to Improve Students' Discipline, Motivation to Learn, and Achievement at School}

Strengthening students' religious convictions through worshipping practices can help build discipline. Teaching students about disciplined worship and highlighting its importance in daily life reaffirms the significance of religion in general life and its role in family resilience (Barbosa et al., 2017) and family management (Dehlendorf et al., 2016), such as for problems related to single-parent families (Enache, 2013) and school (Chen et al., 2015). Practicing worship can help students get back in touch with their religion and use it to overcome discipline problems at school (Abramowitz \& Hellberg, 2020), but they may need to be taught good worshiping practices before they can return to a good religious' state of mind (Farahani, et. al., 2020; Mathew-Geevarughese, Corzo, Figuracion, 2019). Material can be delivered about religious beliefs and the consequences of abandoning worship. Given the cognitive and behavioral factors at play, care is needed in worship. Therapists may also be helpful for someone in need of religious treatment (Giappichelli, 2020). Such treatments help individuals to obey God's commands and accept the importance of believing in, and following, religious orders. Students then develop the self-control to avoid things prohibited by religion, understand sin, and learn to manage risks through religious behavior (Hutagalung, Chew \& Ter, 2020; Khan, Lindridgeb \& Pusaksrikitc, 2017).

The religious ability and strength of individuals also influences how they handle life and the chaos and challenges it can bring (Meine, 2018). Religion can be regarded as being as vital for survival as a daily staple food (McClure, 2017), because its set of values can be applied in life. Christianity teaches about the context of the world (McAdamis, 2011), and the concept of suffering in religious teachings help stabilize people in life (Van Harsel et al., 2019; Majali, 2020). The motivation to achieve (Moghadam et al., 2020) is an important quality to improve in order to overcome obstacles to academic achievement (Abdelrahman, 2020), such as poor discipline at school (Cutumisu, Schwartz \& Mantou, 2020; Ngulani \& Shackleton, 2018). Increasing discipline in worship leads to better discipline at school and a greater motivation to succeed academically (De Loof et al., 2019; Habóka, et. al, 2020). The purposes of this study are to elaborate how worship in Islamic concept enhances psychological learning and in turn develop the practice in teaching and reach the academic achievement of the students.

\section{Theoretical Framework}

This research is focused on Islamic worship, inspiration, and academic achievement theories. Worship was conceived from the holy Quran, which clarifies the role of worship in aligning learning. Worship is transformed into inspiration and academic achievement during the teaching process. In Islam, worship plays a crucial role in increasing learning inspiration 
and achieving academic success. This presents a religious role in the nature and dynamics of a person's personality from a psychological standpoint. Awareness, belief, loyalty, trust, scapular, inspiration, endurance, experience, protection, part of the need, and fortitude emerge as aspects of worship obedience. In the classroom, knowledge of worship improves school discipline (e.g., enter the classroom orderly and observe the subject matter), Muslim prayer five times a day, and desire to learn (e.g., complete school assignments, achieve potential life goals). The psychological significance of studying worship is shown in Figure 1.

\section{Figure 1}

Worship Frameworks May Improve Students' Motivation and Achievement

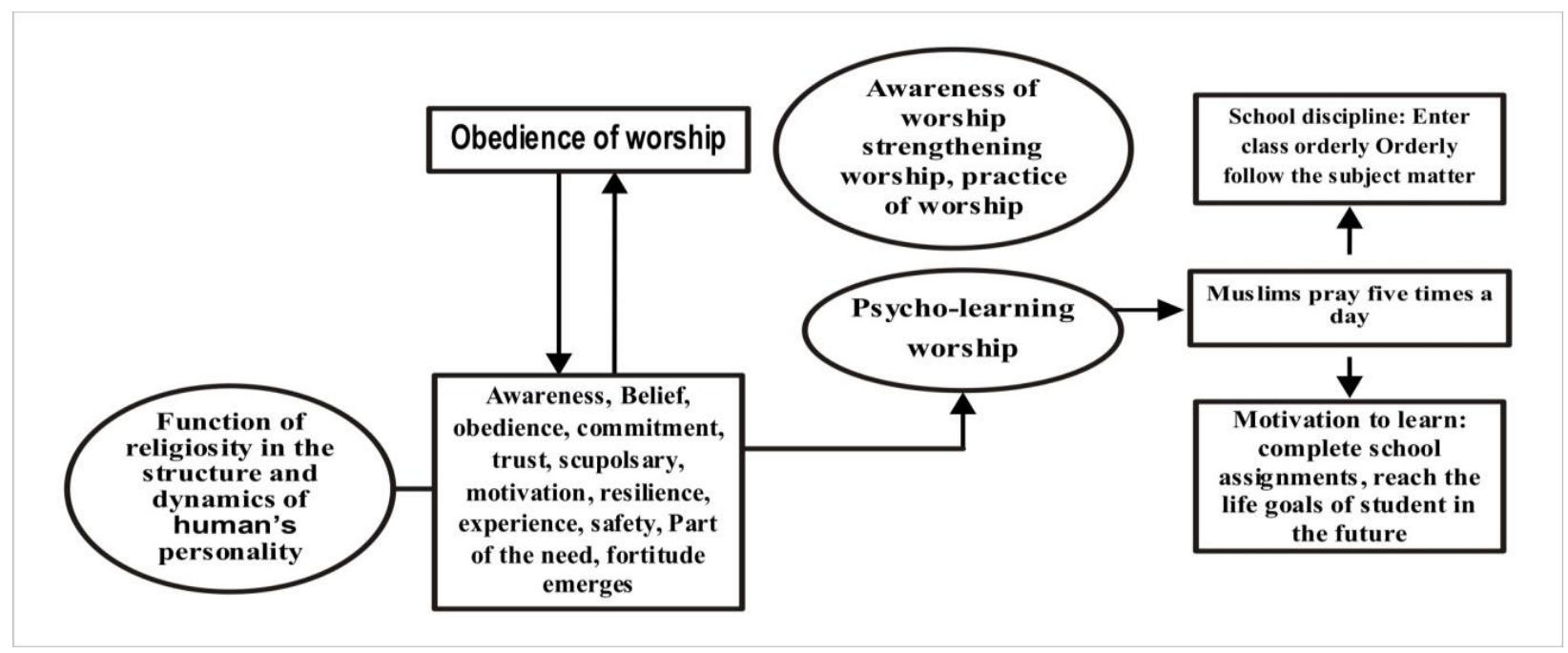

\section{Methods}

Instead of simply studying individual cases, the researcher here has used a qualitative case study design to focus on understanding and interpreting the actions of individuals within the context of a wider system of systems and meanings (Glesne, 2010). It analyzed a real-toapplicable issue from multiple-real life angles (Creswell, 2013). This was done with children and their parents selected purposively in mind. In Tulungagung, East Java, Indonesia, they were 12 years old and stayed in the 6th grade. Since the aim was to bring direct experience and understanding of the students and their parents, the case study design was deemed suitable. Indepth interviews were accompanied by informal and structured discussions about the needs and difficulties, as well as ways to help and inspire students to achieve academic success. From January to June 2020, each participant was interviewed three times. Each interview was 30 to 45 minutes long.

All of the participants' interviews were audio-recorded, full notes were taken during, while other data was obtained, and analysis based on all information; all of this was completed onsite. The researcher transcribed, read, and analyzed all data verbatim. A procedure in which two scholars in Islamic worship and who were considered experts was used to review the study data. When the scholars read all the transcripts and confirmed their claims against the original data, they studied and verified each theme. There was a third person who reviewed the entire data set and the translation, allowing for the data to be proved accurate, the researcher confirmed the reliability of the data, and accuracy of the translations (Lincoln \& Guba, 1985). 


\section{Participants}

Six people took part in this study: four students, two teachers, and one principal. S-1, S-2, S-3, and S-4 were assigned to students, T-1 and T-2 were assigned to teachers, and P-1 was assigned to the principal. Students were monitored, and teachers and the principal acted as informants for information on students' worship and events related to their academic records. Table 1 shows the general conditions for participants.

Table 1

Research Subject Criteria

\begin{tabular}{ll}
\hline Number & \multicolumn{1}{c}{ Criteria } \\
\hline 1 & $\begin{array}{l}\text { Has failed to complete grade VI due to discipline problems in attending class (up } \\
\text { to 60-70 days of absence). }\end{array}$ \\
& $\begin{array}{l}\text { The parents have a low economic status, such as working as a cleaner, only being } \\
\text { able to afford enough food two times a day for themselves and one child, not } \\
\text { having a permanent place to live, and only being able to afford two new t-shirts } \\
\text { and pairs of pants each year. }\end{array}$ \\
& $\begin{array}{l}\text { Not disciplined in practicing worship, even though the subject has memorized } \\
\text { worship practices and can read the Quran. } \\
\text { Subject requires help in getting back to school because he wants to improve his } \\
\text { future prospects. }\end{array}$ \\
&
\end{tabular}

\section{Data-Collection and Analysis}

Observational data were collected for this study. Studying worship and scholastic endeavors were on full display. In addition, students' school records were incorporated into the assignment papers. Observation and data analysis allowed us to narrow down the results to students. Because the interview followed the age-related structure outlined in previous research, it was conducted with the pupils engaged in activities to find out if and fix the problems in mental development.

In-depth interviews with teachers and principals yielded data. Characteristics of each student, academic records, and learning activities during the school day are among the questions to be shared. To show the students' profile, the socioeconomic history of their parents was also included. In particular, each student's interview on Islamic worship was established in relation to their motivation, academic records, worship activities, and parental involvement. School interference as a strategy and teaching programs were also discussed in detail. Data from this transcript was used as the primary source for the study. Data was shown as the story. Using five steps of content analysis, the researcher examined the data (Yin, 2014). Numerical and textual data were obtained through observations and interviews first. In addition, the research questions about the texts were asked from the unit of analysis. the main thrust of worship in teaching was to improve students' attainment Third, the researcher developed the coding system for each unit of analysis. Lastly, the researcher shortens the code phrases that are incorrect. Fourth, the researcher validated each piece of data, as well. 


\section{Results}

\section{Worship to Teach School Disciplines}

The first results of this study describe about how Islamic worship guide students to have discipline attitude at school. This finding indicates that worship can be created from two roles: brainwashing of the obligation from the kyai and implementation of worship practices at school. The role of kyai as an Islamic leader and figure is of prominence so that his speech will be believed to be true. At school, the role of kyai may be replaced by religious teachers and in this regard, the researcher herself. Psychologically, the role of kyai is to create awareness, belief, commitment, trust, scapular and reliance to the students. This way, student will evolve their attitude that Allah observes anything the human does so that the students will have discipline. (Figure 2).

\section{Figure 2}

\section{Implementation of Worship}

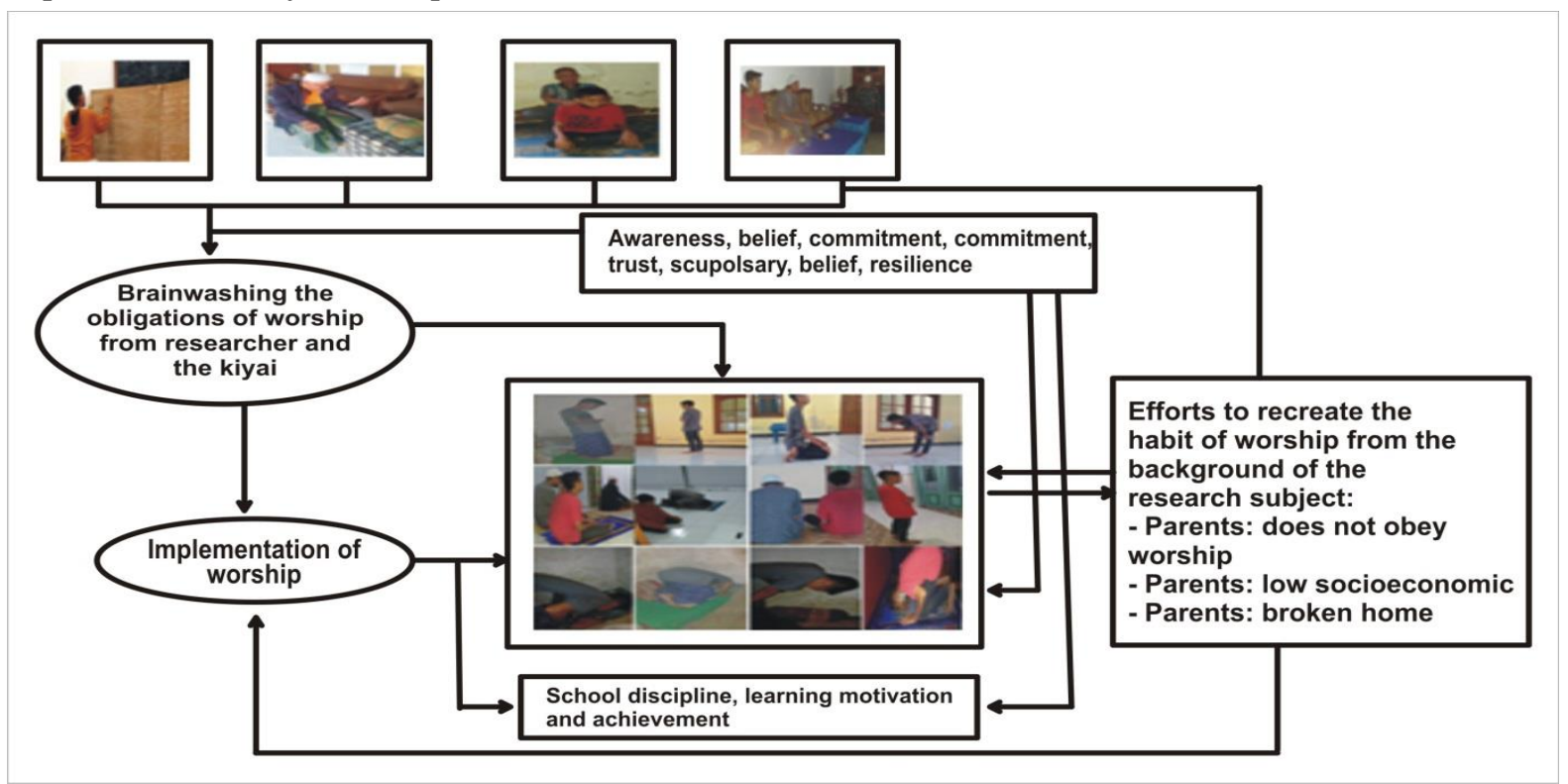

In practice at school, awareness of worship will encourage how school discipline is implemented so that learning motivation and academic achievement improve. First profiles indicate general attitude on religious awareness, the second is the discipline attitude after religious teaching is provided. Results of interview and discussion with teachers, students' express their religious attitude as follows:

- Religion is important to me because it answers questions about my life.

- My religious beliefs lie behind my whole approach to life.

- It is important to spend time in private religious thought.

- I enjoy spending time with others of my religious affiliation.

- Religious beliefs influence all my dealings in my life.

- I spend time trying to grow in understanding of my faith.

- I enjoy working in activities of my religious affiliation.

- I often read books and magazines about my faith.

In addition to school, discipline, students indicate as describe in table 2. It indicates that after religious teachings, basic attitudes of students' discipline improve. 
Table 2

Basic Attitude to Show Students' Discipline After Worship Awareness

\begin{tabular}{|c|c|c|c|c|c|c|c|c|}
\hline \multirow[t]{2}{*}{ Attitude } & \multicolumn{2}{|c|}{ S-1 } & \multicolumn{2}{|c|}{ S-2 } & \multicolumn{2}{|c|}{ S-3 } & \multicolumn{2}{|c|}{ S-4 } \\
\hline & Before & After & Before & After & $(\%)$ & After & Befor & After \\
\hline 1. Coming to the class on time & 56 & 90 & 65 & 95 & 72 & 100 & 68 & 100 \\
\hline 2. Finishing assignment on time & 60 & 85 & 56 & 90 & 68 & 90 & 70 & 100 \\
\hline 3. Praying five times a day & 65 & 87 & 40 & 87 & 58 & 100 & 68 & 100 \\
\hline 4. Praying before and after class & 70 & 90 & 60 & 95 & 48 & 100 & 75 & 98 \\
\hline \multirow[t]{3}{*}{$\begin{array}{l}\text { 5. Responsible to finish } \\
\text { assignment }\end{array}$} & 50 & 85 & 55 & 90 & 56 & 90 & 70 & 100 \\
\hline & 301 & 437 & 276 & 457 & 302 & 480 & 351 & 498 \\
\hline & 60.2 & 87.4 & 55.2 & 91.4 & 60.4 & 96 & 70.2 & 99.6 \\
\hline
\end{tabular}

As table 2 suggests, observation on basic attitude that form students' discipline indicates improvement before and after teaching worship. Before teaching worship is delivered, students' discipline in average is $61.5 \%$, and it increases up to $93.6 \%$ after teaching worship is given. following

Results of observation indicate that discipline in worship can be elaborated into the

- Always remembering the time of worship (100\%)

- Strictly adhering to the time of worship (94\%)

- Striving to worship in any situation $(90 \%)$

- Feeling guilty when neglecting worship (95\%)

In addition to behavior of discipline to arrive at school, there are four indicators that students perform. They are:

- Realizing the importance of going to school to see knowledge (90\%)

- Going to school on time $(100 \%)$

- Realizing that school gives knowledge (90\%)

- Realizing that if you do not go to the class, you will miss learning (90\%)

Regarding the process to form the disciplines, a teacher asserts that the role of Islamic worship is effective to direct students' attitude and efforts.

I observed that students being observed change their attitude. One change his responsibility to come to the class on time; three is little late. In response to the assignments, all students show the full responsibility to finish on time. (T-1)

Having the worship on time, the students are encouraged to apply their discipline at school and their learning process. Efforts have been made to create habits on worship as well as their deeds to learning. However, the principal argues that in some cases, students' motivation is low and it affects students' performance. The principal says: 
We have problems pertaining to motivation. Students whose parents are low in economic background tend to show low discipline. Parents who do not obey the worship and broken home do not pay encourage their sons to have certain discipline in learning at school. (P-1)

\section{Worship to Improve Motivation and Academic Achievement}

This section reports how worship affects learning motivation and academic achievements. At the early stage, students' motivation can be identified through statements the students express as follows:

- Realizing that school is a tool for improving a person's life perspective

- Recognizing the importance of being consistent in learning

- Completing assignment set by teachers

- Stating goals to be achieved in the future

- Hard work in doing tasks and responsibilities

- Do the job correctly and on time?

- Learn together and help each other

- Doing teacher assignments in class and at home in an orderly manner

As Figure 3 suggests, profile of students' motivation before and after teaching the Islamic worship. At the first condition (indicated by A), three conditions on discipline of worship, discipline to go to schools, and motivation and academic motivation, are $40 \%$ for all students. After worship teaching has been delivered (B), the results increase into $90 \%$ in each psychological aspect.

\section{Figure 3}

Students Motivation and Academic Achievement

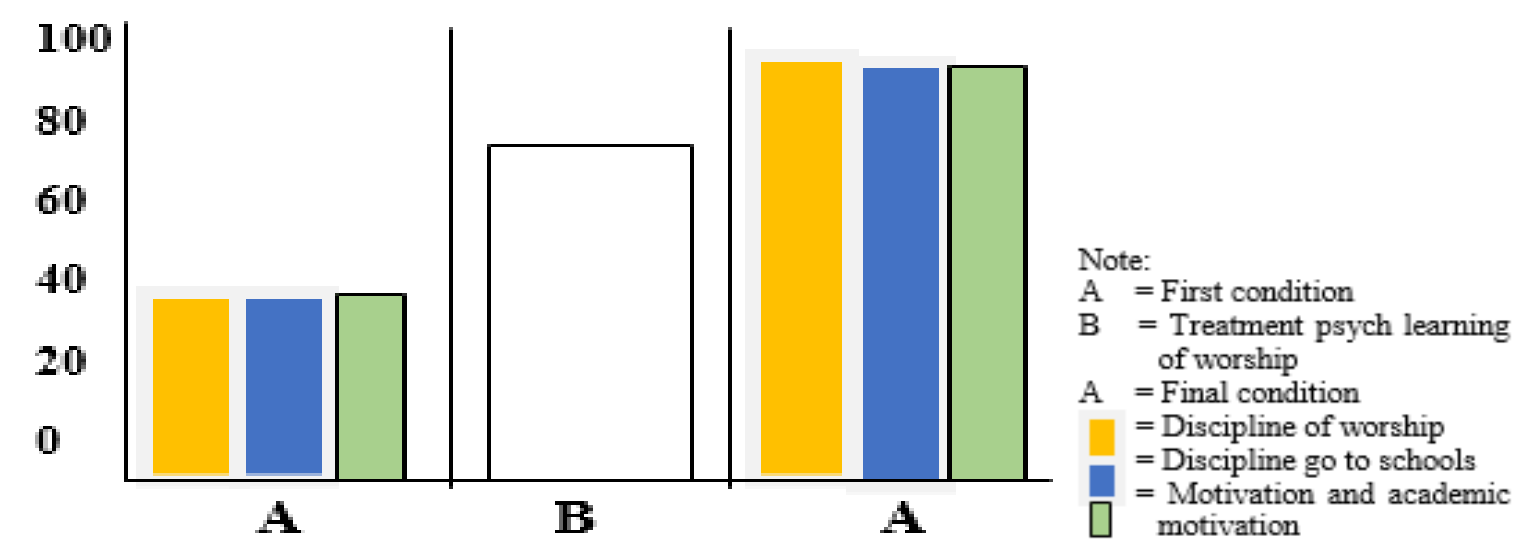

Of the motivation of learning, students indicate high perseverance, the future, and struggle to face problems. In addition, the academic records also improve as it is seen from the learning portfolio, such as workbook, home assignment, projects and scores on homework, assignment, formative test and summative test.

- Arrive at school on time

- Always follow tutoring at school

- Discipline in doing tasks such as doing five daily prayers

- The desire to graduate from school has increased 
- The desire to finish school to a higher-level increase

- Aspire to be a lecturer or employee

- Trying to get a good category score of 80 and above

- Do all tasks in an orderly manner?

- Not easy to give up in the face of adversity

- Always pray for guidance

- Pray to overcome all difficulties at school and at home

In terms of academic achievement, students' profiles can be identified from the following portfolio, namely: Quiz, Class Assignment, Homework, Project, Formative test, Summative test, and Group discussion. Table 3 shows the academic portfolio of the students after teaching worship has been served.

Table 3

Academic Portfolio

\begin{tabular}{lccc}
\hline Academic portfolio & Frequency & Average Score & Achievement (\%) \\
\hline 1. Quiz & 5 & 80 & 80 \\
2. Classroom assignment & 6 & 90 & 90 \\
3. Classroom discussion & 12 & 85 & 85 \\
4. Homework & 6 & 78 & 78 \\
5. Project & 4 & 80 & 80 \\
6. Formative test & 3 & 80 & 80 \\
7. Summative test & 2 & 80 & 80 \\
\hline
\end{tabular}

Table 3 indicates that academic portfolio of the students achieves the target. The minimum attainment $75 \%$ has been reached by students so that the academic achievement has been successfully attained.

\section{Discussion}

Worship instruction increases students' discipline, encouragement, and academic achievement, according to this report. Worship behaviors and qualities that are used to perform Islamic deeds can help with psychological aspects of discipline including worship compliance, worship knowledge, and internal motivation to learn. Students' belief, faith, and struggle increase as a result of being supervised by a kyai, an Islamic leader who teaches the worships, and thus their desire to learn and achieve academic attainments improves.

This study refutes previous research. If a student is religious, she or he will probably get reprimanded (Ahmadi, 2021; Whitford, 2017). Of all of the possible applications, worship is the one with the most positive effect on students in the long term. For students who are still in elementary school, energy, experience, emotion, and motivation is particularly applied to their music, their ability to worship. When someone is not used to doing things in a timely manner, their encouragement leads to their new habits (Tesfagiorgis et al., 2020). Religious activity can have an impact on one's financial well-being. it all goes back to the mentality and the religion and culture: the better the religion and culture a person represents, the more money they tend to make (Bellfield et al., 2018). This coincides with the conclusions of this study, which discovered that educational and personal growth both help to foster a strong work ethic. Strengthening worship activities does, in fact, help to rekindle passion for work and education (Daniel, 2021). 
As a result, any religious teaching can have a significant impact on one's life, and promoting religious practice in everyday life can help to enhance quality of life for both students and the general public (Bandura, 1977; Jeynes, 2003b; McAdamis, 2011). Religious devotion is more than just practicing religion; it also assists an individual in overcoming life's difficulties and achieving happiness and resilience. We looked at how studying worship inspired students to stay in school and finish their assignments in this report. Because of the changes he went through, he became more involved in school, which allowed him to graduate from elementary school and enter junior high school. his discipline was improved, as well as his commitment to his religion, which all led to him attaining (Eott et al., 2005; Gunay \& Aydin; 2015; Jeynes, 2003b; Kalimullina et al. (2021).

Previous research has shown that minority students benefit greatly from devotional activities such as worship (Bandura, 1977; Jeynes, 2003a, 2003b; McAdamis, 2011). This influence includes (a) high expectations, (b) a parental involvement which addresses all students' learning styles, (c) teaching based on culture, (d) a holistic standards, (e) incorporating more of an individualized curriculum, and (f) a faith in the students' abilities to succeed. A number of factors has been noted to diminish the academic achievement of minority students They include (a) limited expectations of both of students and teachers, (b) inability to use their influence, (c) peer support, and (d) a low level of socioeconomic status (Aikenhead, 2001; Allen, 1992; Jeynes, 2003b). Developing a clear understanding of the relationship between these different forces may be a ground-breaking discovery for stakeholders interested in boosting academic achievement for this target population (Logan, 2013; Suskind, 1998).

Religious diversity is common in communities, but from our perspective, it is the practice of a religion that matters, not the religion itself (Fincher et al., 2014). People band together to support disadvantaged and frequently poor minority communities, reinforcing the idea that poverty must be addressed in order to increase overall social welfare (Logan, 2013; Sabirov et. al., 2021). As a result, it is beneficial for religious people to embrace a variety of practices and to treat all fairly. This research explores a number of factors that influenced his academic performance. Powerful parental engagement, religious commitment, high teacher expectations, self-efficacy, avoidance of negative peer pressure, and positive role models are all examples of these factors (Makrooni \& Ropo, 2021; Moradi, 2020; Roth, 2020; Suskind, 1998).

Studies show that it is possible to be happy when you have many beliefs. a person's financial well-being, being if he or she believes in God (Aldashev \& Platteau, 2014). Families are the ideal setting for instilling a real spiritual conviction, moreover, a family is the ideal place to bring up one's faith (Ahmadi, 2021). The findings help support the idea that if someone chooses to return to religious observance, they will do better in their career and life. Religion can also help to develop a strong personality, which prepares a person to do better in life (Aikenhead, 2001; Allen, 1992; Logan, 2013; Sabirov et. al., 2021). As a result, being religious and practicing faith are beneficial to people's lives. When people face difficulties, believing in and practicing a religion will help them cope. When a person completely embraces a religion, he or she is more likely to live a happier life. Since religion is so central to family functioning, it plays an important role in making a family more resilient (Aikenhead, 2001; Logan, 2013; Moradi, 2020).

According to this analysis, when someone abandons their religion, their studies may exhibit a similar lack of discipline. Worship can actually make his or her life more stressful because he or she lacks self-control (Bandura, et. al., 2001). Worship is intended to help people reach their full potential. School tasks would be simple to complete if students will maintain their religious practices. Persistence also creates personal characteristics; as a result, faith aids in the preparation of an individual for the more difficult times of life (Logan, 2013; Moradi, 2020; Turska-Kawa, 2018). 
For a long time, there has been research linking religious engagement and academic achievement. Spiritual and religious involvement has a greater impact on educational outcomes than income does (Jeynes, 2003a). Researcher also discovered that people who hold strong religious values and beliefs tend to do better in mathematics (Hansen \& Ginsburg, 1988). According to social science studies, religious practice has a positive impact on children's educational achievement, which is particularly true for children from low-income communities (Jeynes, 2003a; Regnerus \& Elder, 2003). In many studies, however, researchers have found that students who study the Bible regularly in high school tend to earn better grades, do more homework, while in school, and have fewer academic problems.

Even when taking their socio-economic status, race, and gender into account, devoutly religious students performed better in school than their secular counterparts (disengaged, unteachable) peers, according to Jeynes (2003a) and Regnerus (2000). The qualities of resiliency and accomplishment are usually go hand in hand. Characteristics of resilient, highachieving students are consistently identified in the literature. These students typically have good personal relationships and are actively involved in the community and school. They also demonstrate fitness, superior behavior, problem-solving abilities, and a sense of intent (Bandura, 1977, 2001; Brown et al., 2007).

Academic achievement, interpersonal, institutional, healthy relationships, problem solving abilities, purpose in life, and health are factors in students who have greater depth, participation in the class, school, as well as above-average conduct, traits of determination, increased passion, and enhanced participation are all around them (Ahmadi, 2021; Akpur, 2020; Brown et al., 2007; Logan, 2013). Teachers can see resilience in students if they have loving and competent family members who assist them, if they have connections with parents and other adults who care about their well-being, as well as members of the community who help guide them and advise them. One's own sense of efficacy helps shape all motivation and guides human action, people's confidence in times of struggle impacts their ideas, emotional well-being, and decision-making (Akpur, 2020; Bandura, 1997; Bandura et al., 2001; Logan, 2013; Nasir, 2020).

Ability beliefs are associated with desire for greater educational achievement and desire, Bandura et al. (2001) took a look at self-efficacy beliefs and found that those who had an optimistic and self-efficating belief saw their next on the path to greater success in academic and educational attainment also had the opportunity for professional growth in the chance to strive for more advanced training in medicine. Teachers also found that there was a correlation between a child's educational efficacy and their job potential when a child showed the greatest interest in their career (Logan, 2013; Moradi, 2021). In addition, Barak's (1981) work on vocational preferences supported Bandura's et al (2001) findings on how selfefficacy affected career aspirations. A better understanding of people's perceptions of their ability to meet such work requirements could lead to a better understanding of how people set career goals (Logan, 2013).

\section{Conclusion}

In summary, this study finds that religious worship contributes strong evidence on learning discipline, motivation and academic attainment. Awareness and obedience of to have diligent worship provide the psychological strength for independence and resilience, and this is a useful asset for later life. Intervention in worship though specific religious teaching by religious leaders, teachers, principals and parents in influential to promote endurance and continued willingness to do better in school and improve students' prospects in life. It is effective to teach children five-times prayers to build discipline, such that they also show self- 
discipline in schools and are motivated to improve their grades. Accustoming someone to disciplined prayer is hard work, but families can accomplish this through religious education.

This study discovers that divorced parents, poverty, lapsed religious practice, and weak personality structures meant the family needed support through educational assistance, and religion played an important role in breaking the chain of poverty. In general, students initially had an undisciplined personality, but they became useful persons for society. They went from not praying at all to praying regularly, staying up late to going to bed early, and practicing the five daily prayers. This in turn they improve discipline in attending school. The efforts are made into practice worship is aimed creating a blessed and happy life. In practice, when students learn to create a new pattern of regular disciplined worship, the discipline it builds translates into discipline in attending class and completing assignments if students become aware that this will help them do better later in life. This research is novel in that it positions worship as having an effect on adolescents in more than one way, because it also changes patterns of awareness, not just in terms of prayer but also personality traits that may represent psychological capital for future life. This study regards that limited participants have been observed indicating that more elaboration and in-depth analysis could be developed. Suggestions are made to add the number of the participants, sharing multicultural investigation to improve the study. Future research is directed to conduct survey research that covers quantitative and qualitative insights to explore more details impact of worship to personality development and academic success. In terms of theoretical implications, this study suggests that educators should explore other options when students persistently miss class and do not complete schoolwork before expelling them. Indeed, elementary school provides the foundations for later education, so such children should not be excluded from completing their elementary education if other interventions, such as the one we suggest, may help.

\section{References}

Abdelrahman, M. R. (2020). Metacognitive awareness and academic motivation and their impact on academic achievement of Ajman University students. Heliyon. 6(9), 1-8. https://doi.org/10.1016/j.heliyon.2020.e04192

Abramowitz, J. S., \& Hellberg, S. N. (2020). Scrupulosity. In E. A. Storch, D. McKay, \& J. S. Abramowitz (Eds.), Advanced casebook of obsessive-compulsive and related disorders. Conceptualizations and Treatment (pp. 71-87). Academic Press. https://doi.org/10.1016/B978-0-12-816563-8.00005-X

Addai-Mununkum, R. (2019). Students' representation of "other" religions. Journal of Curriculum Studies Research, 1(1), 1-16. https://doi.org/10.46303/jcsr.01.01.1

Adu-Gyamfi, A. (2020). Connecting religion to homeownership: Exploring local perspectives in Ghana. Cities, 96, 3-17. http//doi.org/10.1016/j.cities.2019.102441

Ahmadi, A. (2021). The traces of oppression and trauma to ethnic minorities in Indonesia who experienced rape on the 12 May 1998 tragedy: A review of literature. Journal of Ethnic \& Cultural Studies, 8(2), 126-144. http://dx.doi.org/10.29333/ejecs/744

Ahmed, Q. A., \& Memish, Z. A. (2019). From the "madding crowd" to mass gatheringsreligion, sport, culture and public health. Travel Medicine \& Infectious Disease, 28, 9197. https://doi.org/10.1016/j.tmaid.2018.06.001

Aikenhead, G. (2001). Students' ease in crossing cultural borders into school science. Science Education, 85(21), 180-188.

Akpur, U. (2020, September). Critical, reflective, creative thinking and their reflections on academic achievement. Thinking Skills \& Creativity, 37, 1-24. https://doi.org/10.1016/j.tsc.2020.100683 
Al Quran ul Kareem, (2020). Altafsir.com. https://www.google.com/search?client=firefox-b$\mathrm{d} \& \mathrm{q}=\mathrm{tafsir}+\mathrm{com}$

Aldashev, G., \& Platteau, P. J. (2014). Chapter 21 - Religion, culture, and development. In V. A. Ginsburgh \& D. Throsby (Eds.), Handbook of the Economics of Art \& Culture, 2, 587-631. http://dx.doi.org/10.1016/B978-0-444-53776-8.00021-0

Allen, W. (1992). The color of success: African American student outcomes at predominantly white and historically black colleges and universities. Harvard Educational Review, 62(1), 26-44.

Aronson, B., Banda, R., Johnson, A., Kelly, M., Radina, R., Reyes, G., Sander, S., \& Wronowski, M. (2020). The social justice teaching collaborative: A critical turn towards critical teacher education. Journal of Curriculum Studies Research (JCSR), 2(2), 21-39. https://doi.org/10.46303/jcsr.2020.8

Bacchetti, L., Bruni, L., \& Zamagni, S. (2020). Growth and the environment in the era of globalization. In L. Bacchetti, L. Bruni, \& S. Zamagni (Eds.), The microeconomics of wellbeing and sustainability (pp. 401-443). Academic Press. https://doi.org/10.1016/B978-0-12-816027-5.00013-6.

Bandura, A. (1977). Self-efficacy: Toward a unifying theory of behavioral change. Psychological Review, 84(2), 191-215. https://doi.org/10.1037/0033-295X.84.2.191

Bandura, A., Barbaranelli, C., Caprara, G. V., \& Pastorelli, C. (2001). Self-efficacy beliefs as shapers of children's aspirations and career trajectories. Child Development, 72, 187206.

Barak, A. (1981). Vocational interests: A cognitive view. Journal of Vocational Behavior, 19, $1-14$.

Barbosa, V. M. J., De Souza, V. W., Ferreira, M. W. R., De Carvalho, F. M. E., Cesse, C. A. E., \& Fontbonne, A. (2017). Correlates of physical activity counseling by health providers to patients with diabetes and hypertension attended by the Family Health Strategy in the state of Pernambuco, Brazil. Primary Care Diabetes, 11(4), 327-336. http://doi.org/10.1016/j.pcd.2017.04.001

Barlow, H. D., \& Hersen, M. (1984). Single-case experimental designs. Strategies for studying behavior change (2nd Ed.). Pegamon.

Bellfield, T., Burke, C., Cullinan, D., Dyer, E., \& Szynalska, K. (2018). Creative discipline in education and architecture: Story of a school. In I. Grosvenor \& L. Rosén Rasmussen (Eds.), Making education: Material school design and educational governance. Educational Governance Research, (Vol. 9, pp. 119-136). Springer. https://doi.org/10.1007/978-3-319-97019-6_6

Bellinger, B. I., Darcangelo, N., Horn, S. S., Meiners, R. E., \& Schriber, S. (2016). Ecologies of school discipline for queer youth: What listening to queer youth teaches us about transforming school discipline. In R. Skiba, K. Mediratta, \& M. Rausch (Eds.), Inequality in school discipline (pp. 135-152). Palgrave Macmillan. https://doi.org/10.1057/978-1-137-51257-4_8

Brown, A., Forde, T., \& Richards, H. (2007). Addressing diversity in school: Culturally responsive pedagogy. Teaching Exceptional Children, 39(3), 64-68.

Budiharso, T., \& Tarman, B. (2020). Improving quality education through better working conditions of academic institutes. Journal of Ethnic and Cultural Studies, 7(1), 99-115. http://dx.doi.org/10.29333/ejecs/306

Capers, K. J. (2019). The role of desegregation and teachers of color in discipline disproportionality. The Urban Review, 51, 789-815. https://doi.org/10.1007/s11256019-00505-6

Chen, J., Huebnerd, S. E., \& Tian, L. (2020). Longitudinal relations between hope and academic achievement in elementary school students: Behavioral engagement as a mediator. 


\section{$\begin{array}{llll}\text { Learning } \quad \text { and } \quad \text { Individual } & \text { Differences, }\end{array}$} https://doi.org/10.1016/j.lindif.2020.101824.

Chen, K., Zong, L., Zhan, Y., Wu, X., Liu, M., \& Jiang, H. (2015). Genetic counseling for a three-generation Chinese family with Waardenburg syndrome type II associated with a rare SOX10 mutation. International Journal of Pediatric Otorhinolaryngology, 79, 745-748. http://dx.doi.org/10.1016/j.ijporl.2015.03.006

Clark, J. (2004). Liberty and religion: The end of U.S. exceptionalism? Orbis, 49(1), 20-53.

Clauson, M. A. (2019). The emergence of conscience rights for health care professionals: How we moved historically from conscience to conscience. Philosophical Consideration, 11, 21-29. https://doi.org/10.1016/j.jemep.2019.100415\%202352-5525.

Creswell, J., \& Wisdom, J. W. (2013). Mixed methods: Integrating quantitative and qualitative data collection and analysis while studying patient-centered medical home models. Retrieved from AHRQ Publication No. 13-0028-EF.

Cutumisu, M., Schwartz, L. D., \& Lou, N. M. (2020). The relation between academic achievement and the spontaneous use of design-thinking strategies. Computers \& Education, 149, 1-13. https://doi.org/10.1016/j.compedu.2020.103806

Daniel, R. G. (2021). Sociology of multicultural identity in the late 1980s and early 1990s: The failure of a perspective. Journal of Ethnic and Cultural Studies, 8(2), 106-125. http://dx.doi.org/10.29333/ejecs/643

De Loof, H., Struyf, A., Boeve-de Pauw, J., \& Petegem, V. P. (2019). Teachers' motivating style and students' motivation and engagement in STEM: The relationship between three key educational concepts. Research in Science Education, (2019), 1-19. https://doi.org/10.1007/s11165-019-9830-3

Deb, K. A. (2018). Surrender to nature': Worldviews and rituals of the small-scale coastal fishers of bangladesh. Marine Policy, 92, 1-12. https://doi.org/10.1016/j.marpol.2018.01.010

Dehlendorf, C., Henderson, T. J., Vittinghoff, E., Grumbach, K., Lee J., Schillinger, D., \& Steinauer, J. (2016). Counseling quality and contraceptive use. Association of the quality of interpersonal care during family planning counseling with contraceptive use. American Journal of Obstetrics and Gynecology, 215(1), 1-32. https://doi.org/10.1016/j.ajog.2016.01.173.

Drake, E. K., Sheffield, D., \& Shingler, D. (2011). The relationship between adult romantic attachment anxiety, negative life events, and compliance. Personality \& Individual Differences, 50, 742-746. https://doi.org/10.1016/j.paid.2010.12.034

Enache, G. R. (2013). Psychological counselling and family planning for teenagers. International Journal Procedia-Social and Behavioral Sciences, 84, 264-268. https://doi.org/10.1016/j.sbspro.2013.06.548

Farahani, F. M., Noruzi, Z. M., Nasiri, M., Shamsikhani, S., Purfarzad, Z., \& Harorani, M. (2020). Effects of extremity massage on preoperative anxiety: A three-arm randomized controlled clinical trial on phacoemulsification candidates. Journal of Perianesthesia Nursing, 35(3), 277-282. https://doi.org/10.1016/j.jopan.2019.10.010

Fincher, R., Iveson, K., Leitner, H., \& Preston, V. (2014). Planning in the multicultural city: Celebrating diversity or reinforcing difference? Progress in Planning, 92, 1-55. http://dx.doi.org/10.1016/j.progress.2013.04.001

Glaeser, E. L., Sacerdote, B., (1999). Why is There More Crime in Cities? Journal of Political Economy, 107, (S6), 225-258. https://doi.org/10.1086/250109. Stable URL

Glesne, C. (2010). Becoming qualitative researchers: An introduction. Pearson Publications.

Gunay, R., \& Aydin, H. (2015). Inclinations in studies into multicultural education in Turkey: A content analysis study. Education and Science, 40(178), 1-22. 
Habóka, A., Magyarb, A., Németha, B. M., \& Csapó, B. (2020). Motivation and self-related beliefs as predictors of academic achievement in reading and mathematics: Structural equation models of longitudinal data. International Journal of Educational Research, 103, 1-12. https://doi.org/10.1016/j.ijer.2020.101634

Hansen, S., \& Ginsburg, A. (1988). Gaining ground: Values and high school success. American Educational Research Journal, 25(3), 334-65.

Hidayah, R. (2021). Students' Self-Adjusment, Self-Control and Morality. Journal of Social Studies Education Research, 10(1), 174-192.

https://www.jstor.org/stable/10.1086/250109

Huang, H., \& Zhu, H. (2017). High achievers from low socioeconomic backgrounds: The critical role of disciplinary climate and grit. Mid-Western Educational Researcher, 29(2), 93-116.

Hutagalung, F., Chew, F. P., \& Ter, T. C. (2020). Motivational intensity as the mediator of orientation and attitudinal with the achievement of Chinese language among the preservice teachers. International Journal of Instruction, 13(4), 941-955.

Hutler, B. (2019). Compromise and religious freedom. Law \& Philosophy, 39, 177-202. https://doi.org/10.1007/s10982-019-09365-3

Jeynes, W. (2003a). Religion, education, and academic success. Information Age Press.

Jeynes, W. H. (2003b). The effects of religious commitment on the academic achievement of urban and other children. Education and Urban Society, 36(1), 44-62. https://doi.org/10.1177/0013124503257206.

Kalimullina, O., Tarman, B., \& Stepanova, I. (2021). Education in the context of digitalization and culture: Evolution of the teacher's role, pre-pandemic overview. Journal of Ethnic and Cultural Studies, 8(1), 226-238. http://dx.doi.org/10.29333/ejecs/347

Karimia, S. M., \& Basu, A. (2018). The effect of prenatal exposure to Ramadan on children's height. Economics and Human Biology, 30, 69-83. https://doi.org/10.1016/j.ehb.2018.05.001.

Khan, A., Lindridgeb, A \& Pusakskrikitc, T. (2017). Why some south Africa Muslims celebrate Christmas: Introducing acculruration trade-off. Journal of Business Research, 82, 290299. http://dx.doi.org/10.1016/j.jbusres.2017.07.023

Li, F. S., \& Qi, H. (2019). An investigation of push and pull motivations of Chinese tourism doctoral students studying overseas. Journal of Hospitality, Leisure, Sport \& Tourism Education, 24, 90-99. https://doi.org/10.1016/j.jhlste.2019.01.002.

Lincoln, Y, \& Guba, E. (1985). Naturalistic Inquiry. Beverly Hills, CA: Sage Publication

Logan, B. C. (2013). The impact of religious commitment and motivation on African American male academic achievement [Doctoral dissertation, Georgia Southern University]. https://digitalcommons.georgiasouthern,edu/etd/824

Majali, S. A. (2020). Positive anxiety and its role in motivation and achievements among university students. International Journal of Instruction, 13(4), 975-986.

Makrooni, G., \& Ropo, E. (2021). Academic learners in Finland: The experiences and perceptions of first-generation migrant family students in higher education. Journal of Ethnic and Cultural Studies, 8(1), 85-106. http://dx.doi.org/10.29333/ejecs/597

Mathew-Geevarughese, S. E., Corzo, O., \& Figuracion, E. (2019). Cultural, religious, and spiritual issues in Palliative care. Primary Care: Clinics in Office Practice, 46(3), 399413. https://doi.org/10.1016/j.pop.2019.05.006

McAdamis, E. M. (2011). Astrosociology and the capacity of major world religions to contextualize the possibility of life beyond earth. Physics Procedia, 20, 338-352. https://doi.org/10.1016/j.phpro.2011.08.031 
McClure, P. K. (2017). Something besides monotheism: Sociotheological boundary work among the spiritual, but not religious, Poetics, 62, 1-13. http://dx.doi.org/10.1016/j.poetic.2017.01.0 01.

Meine, C. (2018). Biodiversity conservation. In D. A. DellaSala \& M. I. Goldstein (Eds.), Encyclopedia of the Anthropocene (Vol. 4, pp. 205-214). Elsevier. https://doi.org/10.1016 /B978-0-12-809665-9.10463-X

Moghadam, T. M., Abbasi, E., \& Khoshnodifar, Z. (2020). Students' academic burnout in Iranian agricultural higher education system: The mediating role of achievement motivation. Heliyon, 6(9), E04960. https://doi.org/10.1016/j.heliyon.2020.e04960

Moradi, E. (2020). Validation of Persian translation of the Intercultural Sensitivity Scale using Rasch Model, Journal of Ethnic and Cultural Studies, 7(3), 63-75. http://doi.org/10.29333/ejecs/374

Ngulani T., \& Shackleton C. M. (2018). Use of public urban green spaces for spiritual services in Bulawayo, Zimbabwe. Urban Forestry and Urban Greening, 38, 97-104. https://doi.org/10.1016/j.ufug.2018.11.009

Ning, B. (2019). Examining the importance of discipline in Chinese schooling: An exploration in Shanghai, Hong Kong, Macao, and Taipei. Asia Pacific Education Review, 20, 489501. https://doi.org/10.1007/s12564-018-9563-4

Patrikiosa, S., \& Xezonakisb, G. (2019). Religious market structure and democratic performance: Clientelism. Electoral Studies, 61, 5-11. https://doi.org/10.1016/j.electstud.2019.102073

Pietkiewicz, J. I., Lecoq-Bamboche, M., \& Hart, O. V. D. (2019). Cultural pathoplasticity in a Mauritian woman with the possession-form presentation: Is it dissociative or not. European Journal of Trauma and Dissociation, 4(2), 1-11. https://doi.org/10.1016/j.ejtd.2019.100131

Polat, S. (2020). Multidimensional analysis of the teaching process of the critical thinking skills. Research in Social Sciences and Technology, 5(2), 134-157. https://doi.org/10.46303/ressat.05.02.8

Ragin, C. C. (2014). The comparative method. Moving beyond qualitative and quantitative strategies. University of California Press Oakland.

Ranz, R \& Alhuzai, N. A. (2019). Beyond the officially secular: Female religious students in the academic space. Women's Studies International Forum, 75, 1-8. https://doi.org/10.1016/j.wsif.2019.102245

Regnerus, D. Mark. (2000). Shaping Schooling Success: Religious Socialization and Educational Outcomes in Metropolitan Public Schools. Journal for Scientific Study of Religion, 39(3), 363-370. DOI: 10.1111/0021-8294.00030

Roth, T. (2020). The role of religion, religiousness and religious participation in the school-towork transition in Germany. Journal of Ethnic and Migration Studies, 46(17), 35803602. https://doi.org/10.1080/1369183X.2019.1620414

Sabirov, A., Sokolovskiy, K., Gromov, E., \& Sabirova, L. (2021). Changes in the understanding of religious and cultural components of human capital. Journal of Ethnic and Cultural Studies, 8(2), 55-67. http://dx.doi.org/10.29333/ejecs/637

Salinas-Vasquez, L., Varela, D. G., Martinez, M. E., \& Jones, D. (2020). A comparative study of the 21st Century Afterschool Center on Education in elementary schools in south Texas. Research in Educational Policy and Management, 2(2), 19-37. https://doi.org/10.46303/repam.2020.2

Skiba, R. J., Mariella, I., Arredondo, I. M., Gray, C., \& Rausch, K. M. (2016). What do we know about discipline disparities? New and emerging research. In R. Skiba, K. Mediratta, \& M. Rausch (Eds.), Inequality in school discipline (pp. 28-31). Palgravve Macmillan. https://doi.org/10.1057/978-1-137-51257-4_2 
Solikhah, I., \& Budiharso, T. (2020). Exploring cultural inclusion in the curriculum and practices for teaching Bahasa Indonesia to speakers of other languages. Journal of Social Studies Education Research, 11(3), 177-197.

Suskind, R. (1998). A hope in the unseen: an American odyssey from the inner city to the Ivy League. Broadway Books.

Tamang, M., \& Shrestha, M. (2021). Let me Fly Abroad: Student Migrations in the Context of Nepal. Research in Educational Policy and Management, 3(1), 1-18. https://doi.org/10.46303/repam.2021.1

Tamika K Williams, K. Tamika; McIntosh, W. Robert \& Russel, B. William. (2021), Equity in Distance Education During COVID-19. Research in Social Sciences and Technology, 6(1), 1-24. https://doi.org/10.46303/ressat.2021.1

Tesfagiorgisa, M., Tsegaib, S., Mengeshac, T., Crafta, J., \& Tessemad, M. (2020). The correlation between parental socioeconomic status (SES) and children's academic achievement: The case of Eritrea. Children and Youth Services Review, 116, 1-9. https://doi.org/10.1016/j.childyouth.2020.105242

Thomas, S., Whitea, G. R. T., \& Samuel, A. (2018). To pray and to play: Post-postmodern pilgrimage at Lourdes. Tourism Management, 68, 412-422. https://doi.org/10.1016/j.tourman.2018.03.021

Tocco, J. U. (2017). The Islamification of antiretroviral therapy: Reconciling HIV treatment and religion in northern Nigeria. Social Science and Medicine, 190, 75-82. https://doi.org/10.1016/j.socscimed.2017.08.017

Turska-Kawa, A. (2018). The centrality of religiosity versus civic involvement: The case of Poland. Communist and Post-Communist Studies, 51(1), 39-48. https://doi.org/10.1016/j.postcomstud.2018.01.002

Van Harsel, M., Hoogerheide, V., Verkoeijen, P., \& Van Gog, T. (2019). Effects of different sequences of examples and problems on motivation and learning. Contemporary Educational Psychology, 58, 260-275. https://doi.org/10.1016/j.cedpsych.2019.03.005

Vaughan, R., Carter, L. G., Cockroft, D., \& Maggiorini, L. (2018). Harder, better, faster, stronger? Mental toughness, the dark triad, and physical activity. Personality and Individual Differences, 131, 206-211. https://doi.org/10.1016/j.paid.2018.05.002

Warman. (2021). Establishing the government policy to promote engagement within the inclusive education system in Indonesia. Journal of Social Studies Education Research, 11(1), 124-148.

Weiss, A. J., Robinson, S., Fung, S., Tint, A., Chalmers, P., \& Lunsky, Y. (2013). Family hardiness, social support, and self-efficacy in mothers of individuals with Autism Spectrum Disorders. Research in Autism Spectrum Disorders, 7, 1310-1317. http://dx.doi.org/10.1016/j.rasd.2013.07.016

Whitford, K. D. (2017). School discipline disproportionality: American Indian students in special education. Urban Review, 49, 693-706. https://doi.org/10.1007/s11256-0170417-x.

Xia, L. X., Ding. C., Hollon, D. S., \& Wan, L. (2013). Self-supporting personality and psychological symptoms: The mediating effects of stress and social support. Personality \& Individual Differences, 54, 408-413. http://dx.doi.org/10.1016/j.paid.2012.10.011

Yin, R., K. (2014). Case Study Research Design and Methods. SAGE Publication Inc.

Yuden, Y., Chuki, S., \& Dorji, T. (2020). Gender sensitivity in pedagogical practices in secondary education in Bhutan. Research in Educational Policy and Management, 2(2), 38-51. https://doi.org/10.46303/repam.2020.3 


\section{Notes on Contributors}

Rifa Hidayah is an Associate Professor of Psychology, Maulana Malik Ibrahim State Islamic University (UIN) Malang, Indonesia. She obtained a Doctorate Degree from Gadjah Mada University (UGM) Yogyakarta, Indonesia. Her areas of teaching include educational psychology, learning psychology, basic research methodology of psychology, measurement and assessment of learning. Her current research interests are: psychology, educational psychology, school psychology, developmental and family psychology, experimental and social psychology, psychological counseling, religious and spiritual psychology.

Elfi Mu'awanah is a professor of counseling guidance at UIN Sayyid Ali Rahmatullah Tulungagung, Indonesia. Earning a Doctorate degree from the State University of Malang, she specifies her teaching some courses: counseling guidance. Her current research interests include: counseling guidance, psychology, religion, spirituality for school and community settings.

Arif Zamhari is an Associate Professor at the Postgraduate School State Islamic University Syarif Hidayatullah Jakarta, Indonesia. He holds Doctorate degree from Australian National University, Canberra, Australia. He teaches Religion and Social Change and Research Methodology course at the school. His research interests cover Islamic spirituality and religious movement.

Munardji is a Professor of educational Management at UIN Sayyid Ali Rahmatullah Tulungagung, Indonesia. Holding a doctorate degree at UIN Maulana Malik Ibarahim Malang, he is now teaching post doctorate degree in disciplines of educational research, management, and practice of strategic and religious-based school education management. His research interests include educational management, religious-based educational management, policy in education management.

Naqiyah is an Associate Professor of Tafisr Alquran a UIN Prof. Saifuddin Zuhri Purwokerto, Indonesia. She obtained a doctorate degree from UIN Syarif Hidayatullah Jakarta, and she is recently teaching Tafsir and Ulumul-Qur'an in the study program of Al-Quran and Tafseer. Her research concentration includes: interpretation, ulumul-Qur'an, living Qur'an, Islam and gender, and Islam and society. 